\title{
Dissemination of bacteria labeled with technetium-99m after laparotomy and abdominal insufflation with different $\mathrm{Co}_{2}$ pressures on rats ${ }^{1}$
}

\author{
Disseminação de bactérias marcadas com tecnécio-99m após laparotomia e insuflação \\ com diferentes pressões de $\mathrm{CO}_{2}$ em ratos
}

\author{
Marcos Bettini PitomboI , Clarice Abreu dos Santos Albuquerque de Faria" , Luciana Camargo Bernardo ${ }^{\mathrm{III}}$, Klaus \\ Steinbruck ${ }^{\mathrm{II}}$, Mario Bernardo Filho ${ }^{\mathrm{IV}}$ \\ I PhD, Associate Professor, Medical Sciences School, UERJ, Rio de Janeiro, Brazil. \\ II Resident, Medical Sciences School, UERJ, Rio de Janeiro, Brazil. \\ III PhD, Biologist, Laboratory of Experimental Radiopharmacy, Instituto de Biologia Alberto Alcântara Gomes, UERJ, Rio de Janeiro, \\ Brazil. \\ IV PhD Biologist, Chairman and Head, Laboratory of Experimental Radiopharmacy, Instituto de Biologia Alberto Alcântara Gomes, \\ UERJ, Rio de Janeiro, Brazil.
}

\begin{abstract}
Purpose: To asses the dissemination of bacteria labeled with technetium-99m $\left({ }^{99 \mathrm{~m}} \mathrm{Tc}\right)$ from peritoneal cavity after different surgical procedures. Methods: Bacteria of the Escherichia coli species labeled with ${ }^{99 \mathrm{~m}} \mathrm{Tc}$ were used in a concentration of $10^{8}$ units of colony-makers for $\mathrm{ml}(\mathrm{UFC} / \mathrm{ml})$ and $1 \mathrm{ml}$ was inoculated through intra-peritoneal via. Forty-eight rats were divided into four groups: control, laparotomy, pneumoperitoneum with $10 \mathrm{mmHg}$ and pneumoperitoneum with $20 \mathrm{mmHg}$ of $\mathrm{CO}_{2}$. Procedures were performed $20 \mathrm{~min}$ after injection of the inoculum and lasted $30 \mathrm{~min}$. Animals were sacrificed after six hours (Group 1) and 24 hours (Group 2). Samples of blood, liver and spleen were collected for radioactivity counting. Results: After six hours, indirect detection of the bacteria in different organs was uniform in all groups. After 24 hours, a larger detection of technetium was observed in the livers of animals of the group insufflated with $20 \mathrm{mmHg}_{\mathrm{m}}$ of $\mathrm{CO}_{2}$, when compared with those of control group $(p<0.01)$. The other groups did not present statistically significant variations. Conclusions: The use of a higher intra-abdominal pressure was associated with a higher bacterial dissemination to the liver. The application of lower intra-abdominal pressures may be associated with a lower dissemination of the infectious status during laparoscopic approach of peritonitis status.
\end{abstract}

Key words: Peritonitis. Pneumoperitoneum. Escherichia coli. Sodium Pertechnetate Tc 99m. Rats, Wistar.

\section{RESUMO}

Objetivo: Avaliar a disseminação de bactérias marcadas com tecnécio-99m $\left({ }^{99 \mathrm{~m}} \mathrm{Tc}\right)$ a partir da cavidade peritoneal após diferentes procedimentos cirúrgicos. Métodos: Foram utilizadas bactérias da espécie Escherichia coli marcadas com ${ }^{99 \mathrm{~m}}$ Tc em uma concentração de $10^{8}$ unidades formadoras de colônia por $\mathrm{ml}$ (UFC/ml) sendo inoculado $1 \mathrm{ml}$ por via intra-peritoneal. Quarenta e oito ratos foram divididos em quatro grupos: controle, laparotomia, pneumoperitôneo com $10 \mathrm{mmHg}$ e pneumoperitôneo com $20 \mathrm{mmHg}$ de $\mathrm{CO}_{2}$. Os procedimentos foram realizados 20 minutos após a injeção do inóculo e duraram 30 minutos. Os animais foram sacrificados após seis horas (grupo 1) e 24 horas (grupo 2). Foram coletadas amostras de sangue, fígado e baço para contagem radioativa. Resultados: Após seis horas, a detecção indireta das bactérias nos diferentes órgãos foi uniforme em todos os grupos. Após 24 horas, observou-se uma maior detecção de tecnécio nos fígados dos animais do grupo insuflado com $20 \mathrm{mmHg}$ de $\mathrm{CO}_{2}$, quando comparados aos do grupo controle $(p<0,01)$. Os outros grupos não apresentaram variações estatisticamente signifícativas. Conclusões: A utilização de pressões intra-abdominais mais elevadas associou-se a uma maior disseminação bacteriana para o fígado. A utilização de pressões intra-abdominais menos elevadas na abordagem da peritonite pode estar associada a uma menor disseminação do quadro infeccioso.

Descritores: Peritonite. Pneumoperitônio. Escherichia coli. Pertecnetato Tc 99m de Sódio. Ratos, Wistar.

1. Research performed at the Laboratory of Experimental Surgery, Medical Sciences School, State University of Rio de Janeiro (UERJ), Brazil. 


\section{Introduction}

Since the 80 s, with the advent of videosurgery, laparoscopic access to peritoneal cavity began to play a very increasing role in the treatment of intra-abdominal affections. The success accomplished with the treatment of biliary vesicular lithiasis paved the way to videolaparoscopy use in divers situations. The good results achieved in gastroenterological, splenic, endocrinal, gynecological and of urgency surgeries have already been largely described. ${ }^{1,2,3}$ Laparoscopic surgery is associated with less pain in the postoperative period and a more precocious return to normal activities when compared with conventional surgery. Nonetheless, the use of laparoscopy in a septical environment and its consequences in a local and systemic level have been the target of a large discussion. The mechanism by which intraperitoneal bacteria have disseminated to the blood current has not yet been clarified.

In diffuse bacterial peritonitis status, the pneumoperitoneum produced through $\mathrm{CO}_{2}$ insufflation may increase the risk of bacterial dissemination, bacteremia and sepsis. ${ }^{4,5}$ This phenomenon has been assessed through experimental models of peritonitis. Nonetheless, results of the researches in this area have been controversial. ${ }^{4,5}$ Ozmen et al. ${ }^{5}$ demonstrated, in one model of abdominal sepsis (intraperitoneal infusion of Escherichia coli (E. coli) colonies in rabbits), a higher risk of bacterial dissemination for organs at a distance in the group submitted to laparoscopy when compared with laparotomized animals. However, in a recent study, we demonstrated a less number of peritoneal cultures and positive hemocultures in mice submitted to cavitary insufflation when compared with animals submitted to laparotomy after intraperitoneal infusion of $0.5 \mathrm{~mL}$ of a solution containing $1 \times 10^{8} \mathrm{CFU} / \mathrm{mL}$ of E. coli. ${ }^{7}$ Other authors did not observe significant alterations in animals that are carriers of peritonitis submitted to laparotomy or cavitary insufflation with $\mathrm{CO}_{2}$ in relation to bacteremia, endotoxemia, and physiological alterations secondary to sepsis. ${ }^{89}$

Several models have been used in the attempt of mimetizing the conditions observed in human peritonitis and sepsis, however, extrapolation of experimental results for clinical practice has been, most of the times, disappointing. ${ }^{10}$

An important challenge nowadays is the development of new models for the study of mechanisms of bacterial dissemination secondary to peritonitis and the impact of several surgical procedures facing abdominal sepsis status.

Within this philosophy, a new experimental model was developed through the use of bacteria labeled with a radioactive isotope (technetium-99m) for assessing bacterial dissemination from peritoneal cavity in rats submitted to laparotomy and peritoneal insufflation with different $\mathrm{CO}_{2}$ pressures.

\section{Methods}

We used a model with rats submitted to laparotomy and pneumoperitoneum produced by insufflation with different $\mathrm{CO}_{2}$ pressures. We conducted the intra-peritoneal inoculation of suspension of E. coli labeled with technetium$99 \mathrm{~m}$. Uptake of this bacterium was assessed through the blood, spleen, and liver of the animals in two different times after inoculation.

The procedures were performed at Laboratory of Experimental Surgery of the Medical Sciences School of the Universidade do Estado do Rio de Janeiro/ UERJ in collaboration with the Laboratory of Experimental Radiopharmacy of the Department of Biophysics and Biometry of Instituto de Biologia Roberto Alcântara Gomes - IBRAG/UERJ. This work was approved by the Ethics Committee on Animal Research of the Laboratory of Experimental Surgery of the Medical Sciences School of UERJ.

\section{Labeling and inoculation of bacteria}

We used bacteria of the species E. coli of the lineage AB1157, obtained in the Laboratory of Experimental Radiopharmacy of IBRAG. Bacteria were labeled with technetium-99m under the form of sodium pertechnetate through a reaction with stannous chloride $\left(\mathrm{SnCl}_{2} \cdot 2 \mathrm{H}_{2} \mathrm{O}\right)$ which acts as a reductor agent for technetium-99m. ${ }^{11}$

A sample of $E$. coli was added to a proper culture medium and incubated from 15 to 18 hours (overnight) at a temperature of $37^{\circ} \mathrm{C}$. From this culture, $200 \mu$ l were withdrawn, put in a culture medium and incubated in agitator for more two hours under the same temperature (reculture). From reculture, we withdrew an aliquot which was homogenized and centrifuged at 4000 rotations per minute (rpm) for 25 min. We despised the supernatant and added SF $0.9 \%$ to the precipitate, which was resuspended and centrifuged successive times until we obtained a suspension of bacteria free from culture medium. This suspension was put in a vacuum tube, and we added stannous chloride as reductor agent of technetium-99m. This solution was diluted, homogenized and then incubated in agitator for $15 \mathrm{~min}$ at $37^{\circ} \mathrm{C}$. Then technetium-99m was added, followed by homogenization, new incubation in the agitator for 10 minutes at $37^{\circ} \mathrm{C}$, and posterior centrifugation at $4000 \mathrm{rpm}$ for $25 \mathrm{~min}$. Supernatant and the resuspended precipate were taken for radioactive counting, and a percentile of labeling of bacteria superior to $95 \%$ was obtained. ${ }^{12}$

A final concentration of bacteria labeled with technetium-99m was obtained corresponding to $10^{8}$ units colony-makers per $\mathrm{ml}(\mathrm{UFC} / \mathrm{ml})$. The inoculated volume was $1 \mathrm{ml}$ per animal through intraperitoneal via.

\section{Animals and procedures}

Male Wistar rats (Rattus norvegicus) weighing 270 $-362 \mathrm{~g}$ were used in this work. Animals were kept in a room with controlled temperature $\left(25^{\circ} \mathrm{C}\right)$ and a 12 hours light/ dark cycle. Animals anesthetized with intraperitoneal sodium thiopental $(40 \mathrm{mg} / \mathrm{Kg})$ received a $1.0 \mathrm{~mL}$ intraperitoneal injection of a solution containing $1 \times 10^{8} \mathrm{CFU} / \mathrm{mL}$ of $E$. coli. Animals were divided into groups of 12 animals according to the type of access to peritoneal cavity as following: Control - absence of any further procedure; Laparotomy 
- animals suffered a $2.5 \mathrm{~cm}$ anterior median abdominal incision; $\mathrm{CO}_{2} 10$ - animals suffered an anterior abdominal puncture with a 20 gauge needle followed by peritoneal insufflation with $\mathrm{CO}_{2}$, maintaining a $10 \mathrm{mmHg}$ intracavity pressure (KARL STORZ ENDOSKOPE - ELETRONIC ENDOFLATOR, model 26430520); $\mathrm{CO}_{2} 20$ - animals suffered an anterior abdominal puncture with a 20 gauge needle followed by peritoneal insufflation with $\mathrm{CO}_{2}$, maintaining a $20 \mathrm{mmHg}$ intracavity pressure. The procedures described were performed $20 \mathrm{~min}$ after the injection of bacterial solution.

Each of the four groups was subdivided into two subgroups according to the time elapsed after bacteria inoculation: Group 1 - sacrificed after six hours of bacterial inoculation; Group 2 - sacrificed after 24 hours of bacterial inoculation. Animals died from a lethal dose of thiopental.

\section{Tissue withdrawal for uptake study}

Animals were submitted to thoracolaparotomy and $1 \mathrm{ml}$ of intra-cardiac blood was aspirated, and liver and spleen were withdrawn and weighed in a precision scale. Liver and spleen fragments were then withdrawn, rightly weighed, and as well as the blood were put in tubes appropriate for radioactivity counting.

\section{Percentile calculation of bacteria uptake}

Percentile calculation of bacteria uptake used a dose standard containing the same volume and the same activity of the E. coli suspension labeled with technetium-99m inoculated in animals. The standard counting was considered as $100 \%$ of radioactivity inoculated in animals. The uptake percentile of each sample was calculated using the formula:

\section{- $\%$ of uptake= \\ Sample counting per minute $\mathrm{x} 100$ \\ Counting per standard minute}

Taking into consideration the liver and spleen mass, the uptake percentile per gram of tissue was calculated by the formula:

$$
\text { - } \% \text { of uptake } / g=\frac{\% \text { of each tissue uptake }}{\text { Mass of each sample }(g)}
$$

The uptake percentile of each organ (total mass) was calculated by the formula:

$\%$ of organ uptake $=\%$ of uptake/g x organ total mass (g)

\section{Radioactivity determination}

The tubes containing fragments of the withdrawn organs and blood were put in appropriate shelves, and radioactivity counting was conducted in a gamma rayscintillometer.

\section{Statistical analysis}

Results were represented as mean and standard error of the mean (SEM) and statistically assessed through Newman-Keuls-Student test, and values considered significant were $p \leq 0.05$.

\section{Results}

\section{Uptake in blood samples}

After six hours, technetium-99m uptake in the blood of the group laparotomized and the group insufflated with $10 \mathrm{mmHg}$ of $\mathrm{CO}_{2}$ presented a mean value discreetly higher, followed by animals of the control group and the group insufflated with $20 \mathrm{mmHg}$ of $\mathrm{CO}_{2}$ pressure. There was no statistical significance between the groups. In the 24 hourassessment, the group insufflated with $20 \mathrm{mmHg}$ of $\mathrm{CO}_{2}$ pressure began to present a more elevated technetium-99m mean uptake, followed by the laparotomy and insufflation groups with $10 \mathrm{mmHg}$ of $\mathrm{CO}_{2}$ pressure. Control group presented a less elevated technetium-99m uptake than the other groups; nonetheless differences were not statistically significant (Figure 1).
BLOOD 6 HOURS

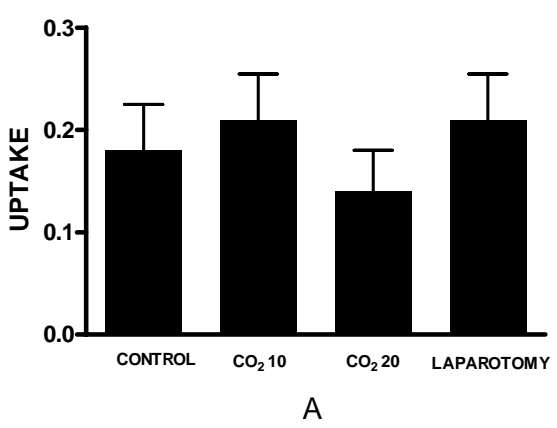

BLOOD 24 HOURS

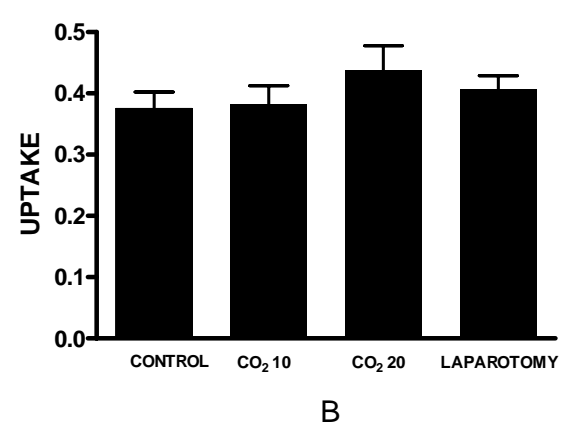

FIGURE 1 - Technetium-99m uptake in the blood after six hours (A) and 24 hours (B). Each bar represents the mean \pm SEM of six animals. There were no statistically significant variations between the groups 
Uptake in spleen samples

In the six hour-analysis, technetium-99m uptake in the spleen of the group insufflated with $20 \mathrm{mmHg}$ of $\mathrm{CO}_{2}$ presented a mean value discreetly higher, followed by animals of the group insufflated with $10 \mathrm{mmHg}$ of $\mathrm{CO}_{2}$ pressure, the laparotomized group and the control group. There was no statistically significance between the groups.
In the second period ( 24 hours), the group insufflated with $20 \mathrm{mmHg}$ of $\mathrm{CO}_{2}$ pressure maintained a more elevated technetium-99m mean uptake, followed by the groups of laparotomy and of insufflation with $10 \mathrm{mmHg}$ of $\mathrm{CO}_{2}$ pressure. Control group began to present a less elevated technetium$99 \mathrm{~m}$ mean uptake than the other groups; however there was no statistically significant relationship (Figure 2).
SPLEEN 6 HOURS

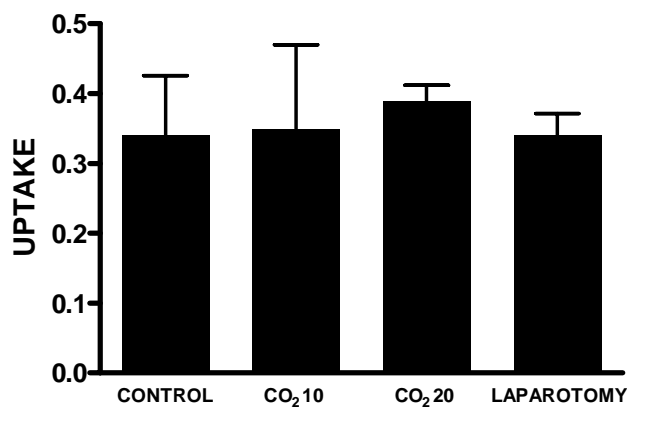

A
SPLEEN 24 HOURS

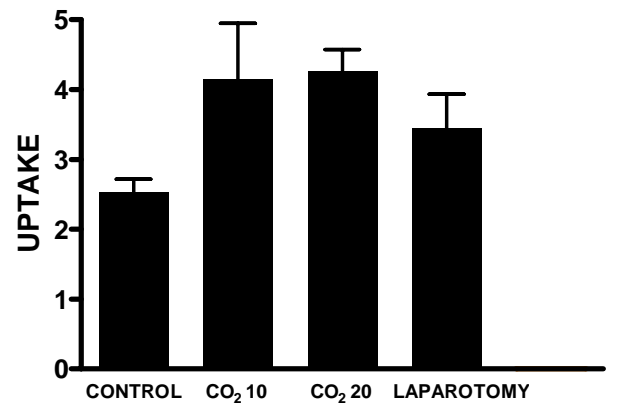

B

FIGURE 2 - Technetium-99m uptake in the blood after six hours (A) and 24 hours (B). Each bar represents the mean \pm SEM of six animals. There were no statistically significant variations between the groups

Uptake in liver samples

After six hours, we observed a technetium-99m uptake in the liver of the laparotomized group with a more elevated mean value, followed by animals of the group insufflated with $20 \mathrm{mmHg}$ of $\mathrm{CO}_{2}$, of the group insufflated with $10 \mathrm{mmHg}$ of $\mathrm{CO}_{2}$ pressure, and of control group. There was no statistical significance between the groups. After 24 hours, the group insufflated with $20 \mathrm{mmHg}$ of $\mathrm{CO}_{2}$ pressure began to present a more elevated technetium- $99 \mathrm{~m}$ mean uptake, with a statistically significant difference in relation to control group $(p<0.01)$. The groups of laparotomy and of insufflation with $10 \mathrm{mmHg}$ of $\mathrm{CO}_{2}$ pressure did not present a significant statistical relationship (Figure 3).

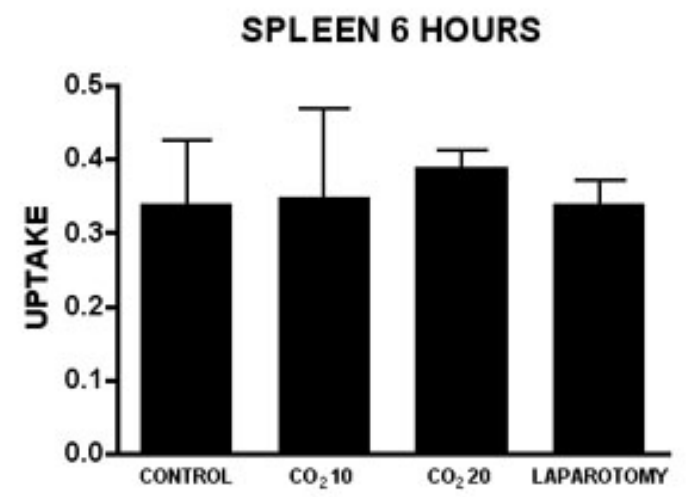

A

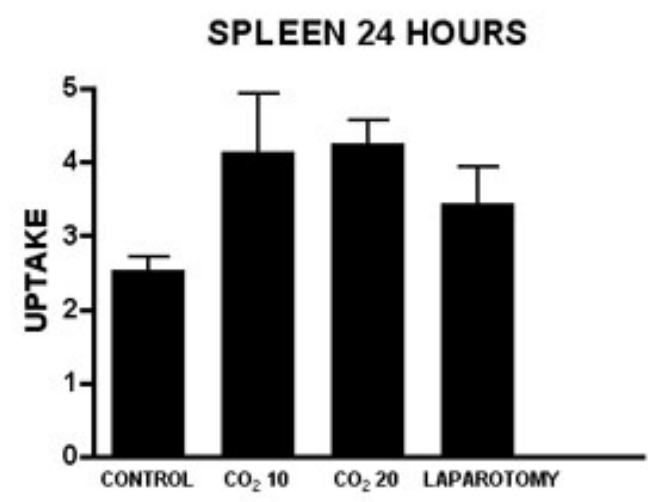

B

FIGURE 3 - Technetium-99m uptake in the liver after six hours (A) and 24 hours (B). Each bar represents the mean \pm SEM of six animals. ${ }^{*} p<0.01$ vs control 


\section{Discussion}

Surgical treatment is a fundamental part of the therapeutic approach of bacterial peritonitis status. Drainage of a septical focus, resection of perforated or necrosed organs, and abundant peritoneal irrigation associated with the adequate clinical treatment represent the best way to solve an intra-abdominal infection. In order to offer the best therapeutical options, it is important to know the impact of surgical trauma on the organism response to pathogenical microorganisms.

Pneumoperitoneum effects on immune response, bacterial dissemination and sepsis development have been extensively studied ${ }^{7,13}$ with the increasing use of the laparoscopic method in statuses associated with peritonitis.

A large variety of animal models have been proposed aiming to analyze many aspects of the laparoscopic approach in the status of peritonitis and sepsis such as: type of gas and different levels of pressure employed in peritoneal insufflation, ${ }^{14,15}$ duration time of pneumoperitoneum, bacterial species inoculated and animal species studied, inoculation via, as well assessment methods. ${ }^{16,17}$

Despite the fact that polymicrobial models such as cecal ligation and puncture (CLP) ${ }^{18}$ and the intra-peritoneal injection of feces ${ }^{19}$ produce a peritonitis status similar to that found in clinical practice where polomicrobial infection prevails, quantification of microorganism dissemination may be complex since the animals may be infected by different bacterial species.

Models that use intraperitoneal infusion of a predeterminate bacterial inoculum are more adequate when what is intended is to analyze the peritoneal clearance of bacteria and its growth in several organic spaces. Besides, they cause a more uniform organic response, which facilitates the analysis of the response to a determinate substance or to surgical intervention. ${ }^{7}$

Among several radiopharmaceuticals used for labeling of biological structures, technetium-99m stands out for its physical chemical characteristics such as high availability, short midlife time, gamma radiation emission, ${ }^{20}$ and for allowing a labeling method relatively simple, effective, fast, of easy assessment, and of low cost. ${ }^{11}$

Studies using bacteria labeled with technetium-99m have already been conducted in order to assess pulmonary bacterial depuration ${ }^{21}$ and bacterial translocation in statuses of hemorrhagic shock ${ }^{20}$ and in obstructive ictericia. ${ }^{22}$

In experimental models of peritonitis, bacterial dissemination at distance has been assessed predominantly through microbiological analysis, cellular countings and dosages of pro-inflammatory cytokines. ${ }^{7,23}$ The use of $E$. coli labeled with technetium-99m in a model comparing the pneumoperitoneum with laparotomy allows the introduction of a new method of study for bacterial dissemination assessment in peritonitis statuses.

Among the parameters used in this work, $10 \mathrm{mmHg}$ and $20 \mathrm{mmHg}$ of $\mathrm{CO}_{2}$ pressures were chosen with the aim of making more evident bacterial dissemination degrees related to different pressures. The same reasoning is applied to the choice of assessment times of six and 24 hours after bacterial inoculation. Different levels of pneumoperitoneum pressure and the time elapsed after bacteria inoculation seem to associate directly with the extension and severity of peritonitis. ${ }^{14,16}$

The higher uptake in the group insufflated with $20 \mathrm{mmHg}$ may be related to the peritoneal reaction to intraperitoneal pressure increase. Volz et al. ${ }^{24}$ experimentally demonstrated, through electronic microscopy, that pneumoperitoneum with $\mathrm{CO}_{2}$ leads to contraction of mesothelial cells causing an opening between intercellular junctions. This phenomenon may facilitate the passage of microorganisms. Besides, the increased intra-abdominal pressure causes an increase of pressure gradient, which associates with the diaphragmatic distension and contributes to bacterial dissemination. ${ }^{25}$

On the other hand, the difference in the uptake observed only in the late group alerts to a discerning assessment of laparoscopy use in peritonitis status with many hours of evolution.

The higher bacteria uptake in the liver may be a consequence of the important role of this organ in the mononuclear phagocytic system. Hepatic detection of bacteria labeled with technetium-99m significantly higher in the group submitted to pneumoperitoneum produced by insufflation with $20 \mathrm{mmHg}$ of $\mathrm{CO}_{2}$ suggests that elevated intra-abdominal pressures may be associated with a higher bacterial dissemination at distance. This datum may have clinical relevance in the surgical approach of bacterial peritonitis status pointing to the need of using less elevated intra-abdominal pressures in this situation.

New studies with the use of labeled bacteria associated with already well established peritonitis models may help to understand the peritoneal dynamics secondary to peritonitis and the phenomena of bacterial dissemination.

\section{Conclusions}

The use of a higher intra-abdominal pressure was associated with a higher bacterial dissemination to the liver. The application of lower intra-abdominal pressures may be associated with a lower dissemination of the infectious status during laparoscopic approach of peritonitis status.

\section{References}

1. Dubois F, Icard P, Berthelot G, Levard H. Coelioscopic cholecystectomy: preliminary report of 36 cases. Ann Surg. 1990 Jan;211(1):60-2.

\section{Marescaux J, Mutter D, Wheeler MH. Laparoscopic} right and left adrenalectomies: surgical procedures. Surg Endosc. 1996 Sep;10(9):912-5.

3. Sanna A, Adani GL, Anania G, Donini A. The role of laparoscopy in patients with suspected peritonitis: experience of a single institution. J Laparoendosc Adv Surg Tech A. 2003 Feb;13(1):17-9. 
4. Evasovich MR, Clark TC, Horattas MC, Holda S, Treen

L. Does pneumoperitoneum during laparoscopy increase bacterial translocation?

Surg Endosc. 1996 Dec;10(12):1176-9.

5. Özmen MM, Col C, Aksoy AM, Tekeli FA, Berberoglu M. Effect of $\mathrm{CO}_{2}$ insufflation on bacteremia and bacterial translocation in an animal model of peritonitis. Surg Endosc. 1999 Aug;13(8):801-3.

6. Palombo JD, Liu K, Greif WM, Rawn JD, Boyce PJ, Forse RA. Effects of laparoscopic vs laparotomy treatment of $E$. coli peritonitis on hemodynamic responses in porcite model. Surg Endosc (1999) 13:1001-1006.

7. Pitombo MB, Lupi OH, Gomes RN, Amancio R, Refinetti RA, Bozza PT, Castro-Faria-Neto HC. Inflammatory response and bacterial dissemination after laparotomy and abdominal $\mathrm{CO} 2$ insufflation in a murine model of peritonitis. Surg Endosc. 2006 Sep;20(9):1440-7.

8. Mendoza-Sagaon M, Hanly EJ, Talamini MA, Kutka MF, Gitzelmann CA, Herreman-Suquet K, Poulose BF, Paidas CN, De Maio A. Comparison of the stress response after laparoscopic and open cholecystectomy. Surg Endosc. 2000 Dec;14(12):1136-41.

9. Mehigan BJ, Hartley JE, Drew PJ, Saleh A, Dore PC, Lee PW, Monson JR. Changes in T cell subsets, interleukin-6 and C-reactive protein after laparoscopic and open colorectal resection for malignancy. Surg Endosc. 2001 Nov;15(11):1289-93.

10. Deitch EA. Animal models of sepsis and shock: a review and lessons learned. Shock. 1998 Jan;9(1):111.

11. Bernardo-Filho M, Pereira JAA, Boasquevisque EM. Labeling of Klebisiella pneumoniae with technetium-99m: a preliminary communication. Rev Microbiol. 1986; 17:188-93.

12. Bernardo-Filho M. Marcação de estruturas biológicas com ${ }^{99 m}$ Tecnécio [Doutorado]. [Rio de Janeiro]: Universidade Federal do Rio de Janeiro, Instituto de Biofísica Carlos Chagas Filho; 1988.

13. Targarona EM, Rodriguez M, Camacho M, Balague C, Gich I, Vila L, Trias M. Immediate peritoneal response to bacterial contamination during laparoscopic surgery. Surg Endosc. 2006 Feb;20(2):316-21.
14. Berguer R, Conrnelius T, Dalton M. The optimum pneumoperitoneum pressure for laparoscopic surgery in the rat model. Surg Endosc. 1997 Sep;11(9):915-8.

15. Horattas MC, Haller N, Ricchiuti D. Increased transperitoneal bacterial translocation in laparoscopic surgery. Surg Endosc. 2003 Sep;17(9):1464-7.

16. Bloechle C, Emmermann H, Treu H, Achilles E, Mack D, Zornig C, Broelsch CE. Effect of a pneumoperitoneum on the extent and severity of peritonitis induced by gastric ulcer perforation in the rat. Surg Endosc. 1995 Aug; 9 (8): 898-901.

17. Balagué C, Targarona EM, Pujol M, Filella X, Espert JJ, Trias M. Peritoneal response to a septic challenge: comparison between open laparotomy, pneumoperitoneum laparoscopy, and wall lift laparoscopy. Surg Endosc. 1999 Aug;13(8):792-6.

18. Wichterman KA, Baue AE, Chaudry IH. Sepsis and septic shock - a review of laboratory models and a proposal. J Surg Res. 1980 Aug;29(2):189-201.

19. Lang CH, Bagby GJ, Bornside GH, Vial LJ, Spitzer JJ. Sustained hypermetabolic sepsis in rats: characterization of the model. J Surg Res. 1983 Sep;35(3):201-10.

20. Arden WA, Yacko MA, Jay M, Beihn RM et al. Scintigraphic evaluation of bacterial translocation during hemorrhagic shock. J Surg Res 1993; 54: 102-6.

21. Johanson Jr WG, Kennedy MG, Bonte FJ. Use of Technetium $\left({ }^{99 \mathrm{~m}} \mathrm{Tc}\right)$ as a bacterial label in lung clearance studies. Appl Microbiol. 1973 April; 25(4): $592-4$.

22. Alencar SSS, Medeiros AC, Brandt CT, Aguiar JLA, Rocha KBF, Silva MP. Translocação de bactérias marcadas com $\mathrm{Tc}^{99}$ na icterícia obstrutiva em ratos. Acta Cir Bras. 2001; 17 (Supl. 1):35-8.

23. Matsumoto T, Dolgor B, Ninomiya K, Bandoh T, Yoshida T, Kitano S. Effect of $\mathrm{CO}_{2}$ pneumoperitoneum on the systemic and peritoneal cytokine response in a LPS-induced sepsis model. Eur Surg Res. 2001;33(2):71-6.

24. Volz J, Koster S, Spacek Z, Paweletz N. Characteristic alterations of the peritoneum after carbon dioxide 
pneumoperitoneum. Surg Endosc. 1999 Jun;13(6):611-

4.

25. Sare M, Demirkiran AE, Alibey E, Durmaz B. Effect of abdominal insufflation on bacterial growth in experimental peritonitis. J Laparoendosc Adv Surg Tech A. 2001 Oct;11(5):285-9.

\section{Correspondence:}

Marcos Bettini Pitombo

Departamento de Cirurgia Geral

Faculdade de Ciências Médicas, UERG

Av. 28 de setembro, 77

20550-030 Rio de Janeiro — RJ Brazil

Phone: (55 21)2587-6310

Fax:(5521)2711-9555

mpitombo@urbi.com.br
Conflict of interest: none Financial source: Fundação de Amparo à Pesquisa do Estado do Rio de Janeiro (FAPERJ)

Received: August 10, 2007

Review: October 15, 2007

Accepted: November 12, 2007

\section{How to cite this article}

Pitombo MB, Faria CASA, Bernardo LC, Steinbruck K, Bernardo Filho M. Dissemination of bacteria labeled with technetium$99 \mathrm{~m}$ after laparotomy and abdominal insufflation with different $\mathrm{Co}_{2}$ pressures on rats. Acta Cir Bras. [serial on the Internet] 2008 Jan-Feb;23(1). Available from URL: http://www.scielo.br/acb 